\title{
PEMIKIRAN KEAGAMAAN MUHAMMAD BASUNI IMRAN
}

\author{
Didik M Nur Haris dan Rahimin Affandi Abd Rahim \\ Akademi Pengajian Islam, Universiti Malaya Malaysia \\ didiknurharis@gmail.com; faqir_ila_rabbih@um.edu.my
}

\begin{abstract}
:
Basuni Muhammad Imran (1883-1976) was an Indonesian reformer who live in Sambas, West Kalimantan, it has brought this area to reach the peak of science and modernity. The main patterns of Muhammad Basuni Imran thought is traditionalism, inclusivism and flexible in medium but strong in thaw a bit. This study revealed substantial contributions of Muhammad Basuni Imran in Islamic legal thought especially in purposes in Islamic laws (maqasid shari'a) and Islamic politic (siyasah shariah), through the implementation of the concept tadarruj, Maslahah mursalah, al-Tahaluf al-Siyasi, and local wisdom of jurisprudence in adopting the opinion of the validity prayers Friday at least 40 people.

Keywords: Muhammad Basuni Imran, West Kalimantan, Ulama, Islamic legal thought.
\end{abstract}

\section{Pendahuluan}

Muhammad Basuni Imran (1883-1976) adalah ulama kharismatik Kalimantan Barat yang pada masanya kawasan kesultanan Sambas mencapai kemuncak keilmuan dan kemodenan, kerancakan pembinaan di bidang keilmuan dan keagamaan inilah yang membawa kawasan ini dikenali sebagai "Serambi Mekah".

Ia hidup sezaman dan seguru dengan beberapa tokoh pembaharuan Indonesia lainnya seperti K.H. Ahmad Dahlan (lahir 1869) pendiri Muhammadiyah, K.H. Hasyim Asy`ari (lahir 1887) pendiri Nabdab al-Ulama $(\mathrm{NU})$, hanya sahaja para tokoh-tokoh nasional sezamannya ini, lebih banyak berperanan pada pertubuhan-pertubuhan kemasyarakatan Islam, manakala Syeikh Muhammad Basuni lebih banyak berperanan di kerajaan atau kesultanan Sambas. 
Antara tokoh yang mengenali Syeikh Muhammad Basuni Imran adalah Buya H. Abdul Malik Karim Amrullah (HAMKA), ianya menyatakan bahawa Muhammad Basuni Imran merupakan "mutiara yang terpendam, ilmu dan pengetabuan Basuni Imran sungguh dalam dan luas". ${ }^{1}$ Rakan seusianya iaitu H. Agus Salim² pernah mengatakan: "Andai sahaja Maharaja Imam Haji Mubammad Basuni Imran duduk berdiam di Jakarta, ilmu dan pengetabuannya akan dapat lebih bermanfaat dan lebih mudah dikembangkan". ${ }^{3}$ Kefasihannya dalam berbahasa Arab juga telah mendapati pujian daripada Prof. Kahar Mudhakkir, guru besar "IAIN Sunan Kalidjaga Yogyakarta", manakala Syeikh Muhammad Basuni Imran membahagikan kuliah umum, ianya mengatakan: "Bahasa Arab Basuni Imran sangat dipujikan", ${ }^{4}$ demikian juga alu-aluan Mahmud Yunus yang menyatakan bahawa H. Muhammad Basuni Imran adalah seorang ulama besar di Sambas. ${ }^{5}$

Justeru Muhammad Basuni semakin dikenali di alam Melayu khususnya dan antarabangsa pada umumnya, saat pertanyaan beliau keatas majalah alManar tentang "Limadha taakhar al-Muslimuna wa limadha taqaddama ghairubum?" (Mengapa Ummat Islam mundur dan orang lain maju?)" menjadi tajuk buku dengan judul yang sama yang ditulis oleh Amir Shakib Arselan (1869-1945). Terjemahannya ke dalam bahasa Inggeris berjudul "Our Decline and its Causes" terbit di Lahore Pakistan tahun $1944,{ }^{6}$ dan terjemahan ke dalam bahasa Indonesia diterbitkan pada tahun 1970-an. Yang menyimpulkan bahawa bukan

\footnotetext{
1 A. Muis Isma'il (1993), Mengenal Mubammad Basuni(Maharaja Raja Sambas). Pontianak: FISIP Universitas Tanjungpura, h. 38.

2 Haji Agus Salim merupakan pahlawan nasional Republik Indonesia, lahir di Minangkabau, 8 Oktober 1884. Pendidikan dasar ditempuh di Europeesche Lagere School (ELS), sekolah khusus kanak-kanak Eropa, kemudian diteruskan ke Hoogere Burgerschool (HBS) di Batavia. Ketika lulus, ianya berhasil menjadi graduan terbaik di HBS se-Hindia Belanda. Ianya mendapati gelaran "Orang Tua Besar" (The Grand Old Man). Beberapa jawatan yang pernah di jawat semasa hidupnya, antararanya, ahli dalam Volksraad (1921-1924), ahli dalam panitia 9 BPUPKI yang mempersiapkan UUD 1945, Menteri Muda Luar Negeri Kabinet Sjahrir II 1946 dan Kabinet III 1947, pembukaan hubungan diplomatik Indonesia dengan negara-negara Arab, terutama Mesir pada tahun 1947, Menteri Luar Negeri Kabinet Amir Sjarifuddin 1947, Menteri Luar Negeri Kabinet Hatta 1948-1949. Ia wafat pada $8^{\text {th }}$ Oktober 1884. "Pahlawan Nasional: K. H. Agus Salim," dicapai 26 Mei 2016, http://www. http://indonesiaindonesia.com/f/4328-pahlawan-nasional-k-h-agus-salim/.

3 Machrus Effendy (1995), Riwayat Hidup dan Perjuangan Maba Raja Imam Sambas (Jakarta: P.T. Dian Kemilau), h 16.

4 Ibid.

5 Mahmud Yunus (1996), Sejarah Pendidikan Islam di Indonesia. Jakarta: Hidakarya Agung, h. 344.

6 G. F. Pijper (1984), Beberapa Studi tentang Sejarah Islam di Indonesia 1900-1950, terj. Tudjimah \& Yessy Augusdin. Jakarta: UI Press, h. 148-149.
} 
agama yang menyebabkan mundurnya ummat Islam, melainkan umat Islamlah yang telah meninggalkan agama Islam. Agama Islam telah berjasa membawa umatnya keatas kebudayaan yang tinggi di masa lalu, sehingga umat Islam pada masa itu unggul dan maju, oleh itu, kejayaan dan kemajuan umat Islam akan kembali, hanya apabila mereka memegangi dan mengamalkan ajaran agama Islam. Oleh itu, G.F. Pijper mengatakan: "Pandangan Muhammad Basuni telah mewakili reformasi Mesir dengan sebenar di Indonesia".

\section{Metode Kajian}

Penelitian ini merupakan penelitian kualitatif dengan menggunakan dua bentuk pendekatan yaitu kepustakaan (library research) dan kesejarahan (historical research). Analisis penelitian ini menggunakan content analysis (analisis kandungan) dengan membuat sebuah kesimpulan secara sistematis dan mengidentifikasi karakteristik tertentu secara objektif dalam sebuah teks terutama karya-karya Muhammad Basuni Imran seperti al-Tadhkīrat Badi'ah fi Ahkām al-Jum'ah, Risalah Cahaya Suluh, Pada Mendirikan Jumaat Kurang daripada Empat Puluh, Kitab al-Nuṣuṣ wa al-Barāhin 'alā Iqāmat al-Jum'ah bimā Duna al-Arba 'in, kitab Tadzkīr, Sabīl al-Najāh fī Tārik al-ṣalāh, Kitab Husn al-Jawāb 'an Ithbāt al-Ahillah bi al-Hisāb, dan kitab al-Janaiz. Kajian ini juga menggunakan metode analisis Building Explanation yang digunakan untuk menjelaskan motif dan alasan disebalik sebuah fenomena yang dapat diambil dari pelbagai sumber utama seperti bukti empiris, catatan atau laporan, teori atau konsep yang spesifik untuk membantu menghubungkan data ke dalam gambaran yang lebih menyeluruh tentang isu-isu pemikiran hukum Islam yang diketengahkan oleh Muhammad Basuni Imran.

\section{Pembahasan}

\section{Suasana zaman semasa Muhammad Basuni Imran}

Sepertimana kepesatan perkembangan Islam di dunia Melayu pada umumnya, begitupun di kawasan Sambas khasnya, selama hampir tiga abad kekuasaan Islam di Sambas telah berlaku pengembangan keilmuan dan keberagamaan Islam secara baik, usaha yang cukup panjang itu tampak daripada hasilnya dengan nyata pada awal abad ke-20, antaranya, pertama, wujudnya ulama-ulama besar yang berperanan seperti Syeikh Ahmad Khatib al-

7 G.F.Pijper (1977), Studien Over de Geschiedenis Van De Islam In Indonesia 1900-1950. Netherlands: E.J. Brill Leiden, h. 134. Pabali H.Musa (2003), Sejarah Kesultanan Sambas Kalimantan Barat, c. 1. Pontianak: Percetakan Romeo Grafika, h. 39. 
Sambasi dan Syeikh Muhammad Basuni Imran, kedua, pembinaan secara rasmi lembaga keagamaan Islam di istana Sambas yang dipimpin oleh seorang Imam kesultanan pada pemerintahan Muhammad Ali Safiyuddin I (memerintah 18131826M), ketiga, Pembinaan masjid yang terletak di hadapan istana pada tahun 1872 M yakni pada masa penguasa Sambas ke-13 bernama Raden Afifin (Muruhum Cianjur) bin Muruhum Tajuddin bergelar Pangeran Adipati atau Sultan Muhammad Safiy al-Din II (memerintah 1866-1922), keempat, Pembinaan Madrasah Perguruan Islam al-Sultaniyab tahun 1922 M. ${ }^{8}$ Meningkatnya kualiti keagamaan dan keilmuan kaum muslim di kawasan Sambas inilah yang pada akhirnya menghantarkan kawasan Sambas mendapatkan gelar sebagai Serambi Mekah.

Kepesatan perkembangan Islam di kawasan Sambas ini menurut Pabali Musa tidak terlepas daripada tiga faktur utama, antaranya pertama: kesejahteraan dan kemakmuran sosial ekonomi kesultanan Sambas, kedua: semangat keilmuan di bidang agama yang dipelopori langsung oleh sultan dan ulama, ketiga, pemodenan yang dibawa oleh penjajah Belanda.

Sememangnya sejak tahun 1818 M kolonial Belanda telah menduduki kawasan Sambas dan mengasas kantor perwakilannya di kawasan ini, ${ }^{10}$ telah membawa kesan negatif keatas pelbagai kebijakan politik keagamaan, seperti usaha memisahkan antara hukum Islam yang merupakan bahagian yang tidak terpisahkan daripada adat Melayu dan rujukan utama dalam seluruh aspek kehidupan dengan hukum adat. Sudah tentu, matlamat utamanya adalah usaha membawa Islam dalam sebuah rumusan yang sempit dan langkah strategik bagi mengekalkan kekuasaan kolonial. Oleh itu, pemerintah Belanda telah menguatkuasakan satu enakmen yang mengandungi beberapa kebijakan, pertama, Islam hanya terhad dalam bidang agama murni (ibadah), kedua, di bidang sosial kemasyarakatan pemerintah memanfaatkan hukum adat sebagai sebuah enakmen perundangan, ketiga, di bidang politik pemerintah harus

8 Machrus Effendi, Op.Cit., h. 20.

9 Pabali Musa (1999), "Muhammad Basuni Imran (1883-1976), Rekonstruksi Pemikiran Maharaj Imam Sambas-Kesultanan Sambas Kalimantan Barat.” Tesis Program Magsiter Pemikiran Islam, IAIN Syarif Hidayatullah, h. 23.

${ }^{10}$ Walau demikian, sejatinya Belanda melalui perusahaan dagangnya VOC ke wilayah Sambas terekod telah lama berada di kawasan ini iaitu semasa Sambas masih berbentuk kerajaan Hindu Buda iaitu dengan adanya perjanjian dagang tarikh 1 Oktober 1609 M. Graham Irwin (2006), Borneo Abad Kesembilan Belas. Terj. Mohd. Nor Ghani dan Noraini Ismail, c. 2. Kuala Lumpur: Dewan Bahasa dan Pustaka, h. 63. 
mencegah setiap usaha yang akan membawa rakyat kepada fanatisme politik pan-Islam. ${ }^{11}$

\section{Salahsilah dan Riwayat Hidup Muhammad Basuni Imran}

Syeikh Basuni Imran lahir di Sambas pada tanggal 25 Zulhijah $1302 \mathrm{H}$ bertepatan dengan 16 Oktober $1885 \mathrm{M}^{12}$ ianya masih terhubung dengan susur keturunan Raja Gipang, penguasa kerajaan Hindu yang terletak di kawasan Sabung Paloh Sambas, yang telah ada semenjak tahun 1479 M. ${ }^{13}$ Sabung ketika itu dipimpin oleh seorang raja yang bernama Gipang. Raja Gipang memiliki empat orang putera, iaitu Tan Panimbang, Tan Panimbul, Tan Bengkirai Tengkirang. Tan Bengkirang mempunyai seorang puteri bernama Tan Siti yang kemudian dinikahkan dengan Datuk Cupu yang berasal daripada Pulau Bintan Riau. Daripada perkahwinan dengan Datuk Cupu, lahirlah empat orang putera, iaitu Datuk Merdun, Datuk Sandi, Datuk Tuyu dan Datuk Sintung. ${ }^{14}$

Daripada keturunan Datuk Sandi yang cukup panjang dan tidak dikenali dengan sebenar lima orang bersaudara iaitu Datuk Jabar, Datuk Basin, Datuk Kahar, Datuk Bandul dan Datuk Mustafa. ${ }^{15}$ Datuk Mustafa mempunyai seorang anak yang bernama Nuruddin yang menjadi Imam Kesultanan. Imam Nuruddin mempunyai tiga orang isteri iaitu Mas Nafsiah, Encik Sa'diyah dan yang ketiga berasal daripada Mekah dan tidak diketahui namanya yang jelas. Daripada perkahwinan dengan Mas Nafsiah, ia mempunyai anak yang bernama Muhammad Arif, ianya kemudian dilantik menjadi Maharaja Imam pertama

\footnotetext{
${ }^{11}$ Sudah tentu kebijakan ini berpaksikan keatas satu tujuan agar kesan Islam di Indonesia dapat dihilangkan dan mempercepat usaha kristenisasi. Sememangnya keadaan ini tidak dapat dipisahkan daripada situasi yang sedang berlaku ketikaitu dimana kekuasaan Turki Uthmani, khasnya di kawasan Eropa telah mulai jatuh dan lemah. Kekalahan demi kekalahan Turki Utsmani telah membangkitkan rasa percaya diri dunia Barat untuk memaksakan ajaran-ajaran agamanya dan melakukan penguasaan kawasan-kawasan Islam. Aqib Suminto (1996), Politik Islam Hindia Belanda. Jakarta: LP3ES, h. 26-63.

12 Meski terdapat percanggahan di kalangan sejarawan tentang tahun kelahiran, namun pengkaji lebih cenderung dengan apa yang di kemukakan G.F. Pijper, sebab merupakan tulisan yang dikirimkan sendiri oleh Basuni Imran kepada pengkaji Belanda ini, sehingga lebih objektif dan autentik. Lihat dalam G. F. Pijper, Op. Cit., h. 142.

${ }^{13}$ Pada masa itu terdapat dua kerajaan Hindu, iaitu Kerajaan Sepudak yang berpusat di Kota Lama Teluk Keramat dan Kerajaan Gipang di Paloh Sambas. Lihat dalam Asal Raja-Raja Sambas, (Manuscrip, Perpustakaan Nasional No. ML.696), h. 1-2.

${ }^{14}$ Abd Muis Ismail, Op. cit. h. 11.

${ }^{15}$ Sesetengah sarjana menjangka bahawa terputusnya susur salsilah keturunan ini disebabkan berpindahnya generasi berikutnya ke dalam agama Islam, perkara ini tampak daripada beberapa nama seperti Jabar, Kahar dan Mustafa. A. Muis Ismail, Op. Cit. , h. 12.
} 
Kerajaan Sambas. Maharaja Imam Muhammad Arif mempuyai dua orang isteri, iaitu Wan Aisyah dan Encik Biru. Perkahwinannya dengan dengan Wan Aisyah memperolehi tiga orang putera, iaitu Rabi'ah, Nawyah dan Muhammad Imran.

Seterusnya, Muhammad Imran mempunyai dua orang isteri iaitu Sa'mi dan Badriyah. Perkahwinan dengan Sa'mi memperoleh empat orang anak iaitu Muhammad Basuni, Muhammad Fauzi, Hamdah dan 'Aishah. ${ }^{16}$

Muhammad Basuni Imran memiliki dua orang isteri, iatu Muzinah binti Imam H. Hamid dan Mas Marhana. Daripada isteri pertama mempunyai enam orang anak iaitu Wahhajah, Hasibah, Sabihah, Hanunah, No'ma dan Muhammad Rasyid. Kemudian daripada isteri kedua terlahir sepuluh orang anak iaitu Mu'anah, Makinah, Sahal, Badran, dawyah, Nazimi, Taqiyuddin, Riyat, Jamaludin dan Mustafa Imam. ${ }^{17}$

\section{Rahalat 'Ilmiah Muhammad Basuni Imran}

Rahalat Tlmiah Muhammad Basuni Imran bermula Pada tahun 1901 M Maharaja Imam Sambas, H. Muhammad Imran mengirim puteranya yakni Muhammad Basuni ke Mekah untuk menunaikan ibadah haji dan meneruskan belajarnya di sana, usianya ketika itu sekitar 16-17 tahun, Syeikh Muhammad Basuni menempoh masa studi di Mekah selama lima tahun (1319-1324 H/1901-1906 M), sepertimana yang ianya ceritakan:

"Pada tahun 1319 (1901-1902), saya dikirim ke Mekah al-Musyarrafah untuk menunaikan ibadah haji dan untuk belajar bahasa Arab dan mendalami pengetahuan tentang Islam. Saya belajar Nahwu dan Saraf dan juga fikih pada Tuan Guru 'Umar Sumbawa dan Tuan Guru 'Uthman Sarawak, sedang dari Tuan Syeikh Ahmad Khatib Minangkabau saya khusus belajar fikih. Saya juga mempelajari segala sesuatu tentang bahasa Arab (nahwu, saraf, ma`ani, badi, bayan), mantiq dan beberapa ilmu pengetahuan lainnya seperti usul fikih, tafsir, dan tauhid dari Syeikh 'Ali Maliki (seorang Arab) dan dari yang lainlainnya"18

Keterangan di atas tampak bahawa pendidikan Syeikh Basuni semasa di Mekah bersifat informal, iaitu halaqah (pengajian melingkar), model pendidikan yang mengemuka pada masa itu. ${ }^{19}$ Sebahagian besar guru-guru beliau semasa di

\footnotetext{
${ }^{16}$ Ibid., 13.

17 Ibid.

18 G.F. Pijper, Op. Cit. , h. 142-143.

${ }_{19}$ Christiaan Snouck Hurgronje (1419 H), Safahat min Tarikbi Makekah dirasah li al-auda' alsiyasiyah wa al-Ijtima'iyyah wa al-Iqtisaddiyah min al-Bithah al-Nabawiyah al-Sharifah wa hatta
} 
Mekah adalah ulama-ulama Melayu seperti Syeikh Umar Sumbawa dan Syeikh Uthman Sarawak, Syeikh Basuni belajar daripada keduanya ilmu Nahwu dan Saraf, manakala dalam bidang Figh beliau belajar kepada Syeikh Ahmad Khatib asal Minangkabau, sedang dalam bidang Usul Fiqh, Tafsir, dan Tauhid Syeikh Basuni belajar kepada Syeikh `Ali Maliki, tampaknya guru yang terakhir inilah berbangsa Arab. Dalam beberapa keterangan penelitian yang lain, Syeikh Muhammad Basuni Imran semasa di Mekah juga telah mendapatkan ijazah (Shahadah) daripada seorang ulama terkemuka di Mekah iaitu Sayid `Abd alHadi al-Bandari. ${ }^{20}$

Pada tahun 1324 H/1906 M beliau pulang ke Sambas atas perintah ayahnya, sejak itu beliau banyak membaca pelbagai buku dari Mesir dan juga majalah Al-Manar yang dipimpin oleh Sayid Muhammad Rashid Rida. Empat tahun kemudian tepatnya pada bulan Zulkaidah 1328 H/November-Desember 1910 M, beliau berangkat ke Cairo Mesir bersama-sama dengan H. Ahmad Fauzi (kakak) dan H. Ahmad Suud untuk menuntut ilmu. ${ }^{21}$

Selama di Mesir, Syeikh Muhammad Basuni meneruskan studi di universitas al-Azhar, kemudian di Madrasah Dar al-Da wah wa al-Irsyad (sekolah kader da i) yang didirikan oleh Muhammad Rashid Rida selama 6 bulan, ianya juga terlibat aktif di majalah Al-Manar dan al-Ijtibad. ${ }^{22}$ Selama lebih kurang 4 tahun belajar di Mesir, Syeikh Basuni telah mendapati dua ijazah daripada dari Sayid M. Ramadan al-Sadfi salah seorang ulama al-Azhar, dan dari Sayid Mubammad Rashid Rida dari al-Manar. ${ }^{23}$

\section{Karya-karya Muhammad Basuni Imran ${ }^{24}$}

Terdapat beberapa karya tulis yang telah terhasil sama ada karya tulis sendiri mahupun terjemahan, sama ada yang berbahasa Arab mahupun Melayu, Syeikh Basuni dalam semua karya tulisnya menggunakan tulisan Arab. Antara karya tulisnya adalah seperti berikut:

1. Tarjamah Durus Tarikh al-Shari at, kitab memiliki 56 halaman muka surat, ditulis pada tahun $1330 \mathrm{H} / 1912 \mathrm{M}$ merupakan terjemahan dari kitab Durus Tarikh karya Syeikh Muhy al-Din al-Khayyat, kitab ini masih dalam bentuk manuskrip yang merupakan karya pertamanya dan satu-satunya

nihayat al- Qarn al- Thalits 'Ashar al- Hijri, ed. 'Ali 'Audah al-Shuyukh, Dar al-Malik 'Abd 'Aziz, h. 503, 513-514

${ }^{20}$ Pabali Musa, Muhammad Basuni Imran (1883-1976), h. 12.

${ }^{21}$ G. F. Pijper, Op. Cit. , 143-144.

22 A. Muis Ismail, Op. Cit., h. 19.

${ }^{23}$ G.F. Pijper, Op. Cit., h. 145-146.

${ }^{24}$ Ibid. 
yang ditulisnya secara sempurna dalam satu buku ketika masih berada di Mesir.

2. Kitab Bidayah al-Tawbid fi Ilm al-Tawbid. Ditulis pada tahun 1336 H/1918 M, kitab ini memiliki 59 halaman muka surat, diterbitkan oleh percetakan al-Ahmadiyah Singapura pada tahun yang sama dengan penulisannya.

3. Risalah Cabaya Sulub. Pada Mendirikan Jumaat Kurang daripada Empat Puluh. Selesai ditulis pada tahun 1339 H/1920 M, memiliki 19 halaman muka surat, diterbitkan oleh percetakan al-Ikhwan Singapura, pada tahun yang sama dengan penulisannya.

4. Tadbkir Sabil al-Najah fi Tarikh al-Salah (jalan keselamatan untuk mengingatkan orang yang meninggalkan salat), selesai ditulis pada tahun $1349 \mathrm{H} / 1930 \mathrm{M}$, tebal 36 halaman, diterbitkan oleh percetakan alAhmadiyah Singapura pada tahun 1349 H/1931 M.

5. Khulasah al-Sirah al-Mubammadiyah, (Hakikat Seruan Islam, ringkasan sejarah Muhammad, hakikat seruan Islam). Karya ini merupakan terjemahan dari kitab Kbulasab al-Sirah al-Mubammadiyah karya Muhammad Rashid Rida. Kitab Kbulasah ini merupakan intisari dari kitabnya yang lain berjudul Dhikra al-Mawlid al-Nabawi, (memperingati kelahiran Nabi). Selesai diterjemahkan pada tahun 1349 H/1931 M, dengan 89 halaman muka surat, diterbitkan oleh percetakan alAhmadiyah, Singapura, pada tahun $1351 \mathrm{H} / 1932 \mathrm{M}$.

6. Terjemah kitab Dhikra al-Mawlid al-Nabawy karya Muhammad Rashid Rida. Terjemahan ringkas yang memiliki 12 halaman muka surat ini menjadi tambahan dalam kitab Khulasah yang ditulis pada bulan Ramadan 1347 H (sekitar tahun 1929 M) dan terbit pada tahun 1351 H/1931 M.

7. Nur al-Siraj fi Qissah al-Isra' wa al-Mi 'raj (cahaya pelita pada cerita Isra' dan Mi raj). Selesai ditulis pada tahun $1334 \mathrm{H}$, kemudian direvisi tahun 1357 $\mathrm{H} / 1938 \mathrm{M}$ dan diterbitkan pada tahun yang sama oleh percetaka alAbmadiyah, Singapura, Tebal 26 halaman muka surat.

8. Kitab al-Jana'ir, (kitab tentang jenazah). Selesai ditulis pada tahun 1362 H/1943 M, terdapat 52 halaman muka surat, tahun dan tempat penerbitan belum diketahui.

Terdapat karya tulis Syeikh Muhammad Basuni yang belum ditemukan. Berikut ini beberapa risalah yang ditulis oleh Syeikh Muhammad Basuni namun belum ditemukan naskahnya. Informasi tentang karya tulis berikut ini diperoleh 
dari tulisan G. F. Pijper dan keterangan dari Muhammad Basuni yang dikemukakannya di dalam beberapa karya tulisnya yang ada. ${ }^{25}$

9. Manhal al-Gharibin fi Iqamah al-Jumu ah bima duni al-Arba in, (pendapat orang-orang yang asing tentang melaksanakan salat Jumaat yang kurang dari 40 orang). Ditulis pada 14 Ramadan 1332H/1914 M, mungkin tidak diterbitkan karena menurutnya risalah ini masih berlanjut. ${ }^{26}$

10. Al-Tadbkirah al-Badiab fi Abkam al-jumiah, (peringatan bagi yang mengada-ada tentang hukum-hukum salat Jumaat). Risalah ini merupakan kelanjutan dari risalah Manhal, selesai ditulis dalam bahasa Arab pada tanggal 17 Muharram 1339 H/1920 M. Menurut keterangan penulisnya risalah ini juga masih bersambung ${ }^{27}$ dan boleh jadi edisi daripada kedua kitab ini yang lengkap adalah kitab Al-Nusus wa al-Barahin.

11. Al-Nusus wa al-Barabin 'ala Iqamah al-Jumi ab bima duna al-Arba ïn, (beberapa nas dan argumentasi dalam melaksanakan salat Jumaat kurang dari 40 orang). Karya tulis ini merupakan edisi bahasa Arab dari kitab Risalab Cabaya Suluh, diterbitkan oleh percetakan al-Manar Cairo tahun $1344 \mathrm{H} / 1925 \mathrm{M}$.

12. Durus al-Tawbid, (pelajaran-pelajaran Tauhid). Menurut keterangan Pijper karya ini merupakan terjemahan dari kuliah-kuliah yang disampaikan oleh Muhammad Rashid Rida.

13. Irshad al-Gbilman fi Adab Tilawah al-Qur'an, (petunjuk praktis tentang adab membaca al-Quran), tempat dan tahun terbitnya belum diketahui.

14. Husn al-Jawab 'an Ithbat al-Abillah bi al-Hisab, (molek jawaban tentang menetapkan awal bulan dengan hitungan). Diterbitkan di Penang tahun 1938 M. Melihat judulnya dapat dipastikan kitab ini membahas tentang cara-cara menetapkan awal bulan Ramadan dan awal bulan Syawal dengan cara penghitungan (bisab) dan melihat bulan (ru'yah).

15. Daw 'u al-Misbah fi faskh al-Nikah, (sinar lampu untuk membatalkan suatu pernikahan). Tempat dan tahun terbitnya belum diketahui. Menurut penjelasan beliau kepada G. F. Pijper bahwa yang disebut ta 'liq adalah adalah talak yang dikenakan persyaratan dan diucapkan pada waktu upacara pernikahan dilangsungkan. Kebiasaan ini tidak dikenal di kawasan Sambas. Pembatalan pernikahan biasanya dilaksanakan dengan jalan fasakh (menyatakan tidak berlaku lagi). Tentu saja harus ada alasan

${ }^{25}$ G. F. Pijper, Op. Cit. , h. 147-148.

${ }^{26}$ Muhammad Basuni 'Imran (13339 H), Risalah Cahaya Suluh. Singapura: Al-Ikhwan, h. 2.

${ }^{27}$ Ibid, h. 2-3. 
yang kuat untuk dapat mengajukan fasakh dan ini harus diajukan kepada Maharaja Imam, beliaulah yang menangani semua urusan yang berhubungan dengan fasakh di seluruh kerajaan Sambas. ${ }^{28}$

\section{Corak Utama Idea Pemikiran Muhammad Basuni Imran}

Corak utama idea pemikiran yang cuba ditawarkan Syeikh Basuni Imran berpunca daripada keteguhan kaum tradisionalis (tradisionalism) ${ }^{29}$ dan keterbukaan kaum reformis (inklusifism), sangat menghargai Turath (warisan ilmu para ulama), namun mesra dalam wasilah dan sarana, kukuh dalam thawabit (perkara-perkara yang tetap) namun lentur dalam mutaghayyirat (perkara yang berubah). Apa yang oleh Pabali dinyatakan sebagai bingkai universalisme keilmuan. ${ }^{30}$ Dalam keterangannya kepada Pijper beliau menyatakan:

"Segala puji bagi Allah (Alhamdulillah)! Walaupun saya telah meninggalkan guru-guru saya, juga telah meninggalkan bangku sekolah di Dar al-Da wah wa al-Irshad, saya tetap (tanpa henti-hentinya) mendalami kitab-kitab Imam Shafi i, kitab-kitab mazhab lain, kitabkitab tafsir Quran dan Hadith, terutama Tafsir al-Manar, majalah alManar, dan juga kitab-kitab lain tentang bermacam-macam ilmu pengetahuan. Untuk meningkatkan kemampuan saya, maka saya pun melatih diri dengan menulis kitab-kitab atau risalah-risalah dalam bahasa Indonesia maupun bahasa Arab, juga dengan mengajukan persoalan-persoalan tentang soal-soal agama, lewat surat kepada Sahib al-Manar [Rashid Rida], pada waktu itu dia masih hidup. Dan saya membaca tafsir, Hadith, atau sesuatu yang lain pada hari Jumaat di masjid jami`Sambas atau kadang-kadang di masjid lain di Sambas"."

Sikap dan pandangan universalisme keilmuan Syeikh Basuni Imran ini telah mewujudkan pembinaan satu corak pemikiran yang unik berteraskan semangat reformisme dan bertumpu keatas paduan pemikiran tradisionalisme

28 G. F. Pijper, Op. Cit. , h. 147.

${ }^{29}$ Tradisionalisme didefinisikan oleh sesetengah sarjana sebagai suatu sikap dan cara berpikir serta bertindak yang selalu berpegang teguh pada norma dan adat kebiasaan yang ada secara turun temurun. Kamus Besar Bahasa Indonesia, h. 959.

30 Universalisme keilmuan bermaksud menerimapakai secara konsisten ijtihad ulama mazhab Shafi'i, namun tetap objektif, kritikal dan inklusif, ianya menghargai semua khazanah ilmu pengetahuan, termasuk ilmu agama, dan menerima di antaranya yang paling benar. Pabali Musa (2002), Kiprah anak zaman, gagasan, pemikiran dan buah karya Maharaja Imam Sambas H. Basyuni Imran. Pontianak: Pusat Penelitian Budaya Melayu Universitas Tanjung Pura, h. 42

${ }^{31}$ G. F. Pijper, Op. Cit., h. 145. 
dan neo-sufisme. Pengembangan ketiga corak pemikiran ini lebih bertujuan untuk mengembalikan kemurnian ajaran Islam (purivication) dan pembinaan wasilah dan institusi yang lebih moden (Islab). ${ }^{32}$

\section{Muhammad Basuni Imran dan Konsep Tadarruj}

Muhammad Basuni Imran berusaha menjaga maslahat dan mengelakkan mudarat dalam pelbagai ijtihad hukumnya (maqasid al-Shari'ab). Penerokaan ke atas kandungan karya-karya yang telah terhasil, kita akan menemukan bahawa Muhammad Basuni Imran mengetengahkan idea pembaharuannya dalam dua fasa, pertama, idea dan pemikiran yang beliau ketengahkan pada kurun sebelum tahun 1931, kedua, idea dan pemikiran selepas masa tahun 1931, usaha ini dalam pandangan penulis merupakan sebentuk tahapan (tadarruj) yang dimaksudkan bagi menjaga keutuhan dan persatuan masyarakat kawasan Sambas (maslahat) yang masih sederhana pemahamannya terhadap ajaran agama dan masih terjejas dengan budaya taklid yang melampau, sehingga dengan usaha secara bertahap ini akan mengelakan percanggahan dan konflik secara berterusan (mafsadab).

Pada fasa pertama, selepas Muhammad Basuni Imran dilantik menjadi Maharaja Imam mufti kerajaan Sambas melihat bahawa masyarakat Sambas belum memiliki kesiapan untuk menerima idea pembaharuan, oleh itu, pada farsa ini Syeikh Basuni lebih menumpukan idea-ideanya ke atas usaha untuk membetulkan dan meluruskan kembali pelbagai ajaran dan amalan dalam aspek akidah, ibadah mahupun akhlak. Perkara ini dapat dilihat daripada karyakaryanya pada fasa ini seperti kitab Tarjamah Durus al-Tarikb Syari'at (1912), yang mengandungi pembahasan tentang sejarah manusia, nabi-nabi dan perkembangan dakwah dan hukum Islam, Bidayah Taubid fi Tlmi al-Taubid (1918), ${ }^{34}$ kitab ini membincangkan hukum seorang muslim yang mukallaf

32 Mengikut pendapat Pabali bahawa corak pemikiran yang sedemikian ini merupakan kesan beberapa faktur utama; pertama, jaringan keilmuan dan ulama yang puritanistik dan neomodernistik yang berpusat di timur Tangah. Kedua, realiti daripada masyarakat Sambas yang feodalistik dan mistik. Ketiga, cabaran baru yang modernistik. Pabali Musa, "Mubammad Basuni Imran (1883-1976), Rekonstruksi Pemikiran Maharaja Imam Sambas-Kesultanan Sambas Kalimantan Barat (Tesis Program Magsiter Pemikiran Islam, IAIN Syarif Hidayatullah, 1999), 100.

${ }^{33}$ Kitab ini merupakan manuskrip terjemahan kitab Durus al-Tarikh karya Syeikh Muhyi al-Din al-Khayyat ke d alam bahasa Arab Melayu. Terjemahan ini ditulis ketika berada di Mesir iaitu pada 17 hb Ramadan 1330 M (30 Agustus 1912 M), setahun sebelum Syeikh Basuni pulang ke Sambas. Manuskrip ini setebal 56 muka surat dan disimpan di Istana Kerajaan Sambas.

${ }^{34}$ Kitab ini ditulis pada hari Rabu 13 Jumadil akhir 1336 H (27 Maret 1918 M) terdiri daripada 59 muka surat. Kitab merujuk kepada sejumlah sumber, iaitu kitab al-Jawabir al- Kamaliyah 
mempelajari asas-asas agama dan kewajipan bagi yang berilmu untuk mengajar kepada yang tidak berilmu. Kitab ini juga membahas masalah-masalah tauhid seperti rukun iman, mukjizat, sibir, hisab, shafa'at, surga dan neraka dan lainlainnya. Pada bab akhir daripada kitab ini dibahaskan masalah-masalah dalam bentuk soal jawab yang berhubungkait keimanan seperti bagaimana kita mengetahui adanya Allah, umat siapa yang lebih utama dari hari kiamat, makna isra' dan mi'raj, surga itu nikmat jasmani atau rohani dan sebagainya. Cahaya Sulub (1920), ${ }^{35}$ kitab ini ditulis sebagai jawapan ke atas soalan daripada masyarakat Sambas tentang hukum mendirikan salat Jumaat yang kurang daripada 40 orang. Dalam kitab ini dibahaskan syarat-syarat sah salat Jumaat, fardu Jumaat, sunnat-sunnat Jumaat, selepas itu pembahasan yang ditulis dalam bentuk soal jawab. Dan kitab terakhir pada fasa ini adalah Kitab Tadhkir, Sabil al-Najah fi Tarikh al-salat (1931 M), ${ }^{36}$ kitab ini membahaskan secara ringkas salat mengikut petunjuk al-Quran dan hadith serta pendapat ulama, yang kemudian di akhiri dengan sebuah kesimpulan.

Pada fasa kedua yang dimulai dengan berakhirnya pemerintahan Sultan Muhammad Ali Syafi'udin II (1922-1931), Syeikh Muhammad Basuni melihat bahawa pelaksanaan syariah Islam di Sambas sudah semakin kukuh dan benar. Oleh itu, dalam masa-masa ini karya-karya beliau semakin mengetengahkan idea-idea pemikiran yang sangat terkesan oleh warna pemikiran Syeikh Ahmad Khatib al-Minangkabawi dan pembaharu asal Mesir Syeikh Rashid Rida, diantara karyanya pada fasa ini, Kitab Khulasah Sirah al-Mubammadiyah (1932) ${ }^{37}$, kitab ini mengandungi 131 halaman muka surat yang membahaskan petunjukpetunjuk bagi orang-orang Islam kepada jalan kebenaran dan kebaikan serta mengajak orang lain untuk masuk Islam, selain itu, kitab ini juga mengandungi tafsir-tafsir al-Quran, dan pada bahagian akhir daripada kitab ini dibahaskan hukum bid'ah daripada Maulid Nabi S.A.W., Kitab Nur al-Siraj fi Qissah al-Isra' wa

karya Syeikh Tahir al-Jazairy, Kitab Kalimah Taubid karya Syeikh Husin Wali al-Misry, dan Kitab Kifayat al-awam. Kitab ini dicetak di Singapura pada percetakan al-Matba'ah alAhmadiyah.

${ }^{35}$ Kitab ini ditulis pada 17 Ramadhan 1339 H (1920 M) yang terdiri daripada 19 halaman muka surat dan diterbitkan oleh al-Matba'ah al-Ahmadiyah Singapura.

36 Kitab ini selesai ditulis dan dicetak pada 23 Sha'ban 1349 H (21 Januari 1931 M) yang mengandungi 34 halaman muka surat. Kitab diterbitkan oleh al-Matba'ah al-Ahmadiyah Singapura.

${ }^{37}$ Kitab ini merupakan terjemahan daripada karya Sayid Muhammad Rida dan dicetak di Singapura pada tahun 1931. Muhammad Basuni Imran, Khulasab Sirah al-Mubammadiyah (Singapura: Matba'ah al-ahmadiyah, 1932). 
al-Mi'raj (1938), ${ }^{38}$ kitab ini selesai ditulis pada hari Jum'ah 23 hb Jumadi alAkhir 1347, mengandungi 26 halaman muka surat, yang membincangkan cerita isra' dan mi'raj yang dirujuk daripada riwayat-riwayat hadith yang sahih dalam hadith Bukhari mahupun Muslim, oleh Syeikh Basuni Imran kemudian diterjemahkan dengan judul "Cahaya Pelita pada cerita Isra' dan mi'raj". Kitab Dau' al-Misbah fi Faskh al-Nikah (1938), kitab ini dicetak di Penang, membahas suatu permasalahan yang wujud dalam kehidupan beragama dan mesti diselesaikan mengikut petunjuk syariah Islam iaitu masalah faskh nikah, menurut Muhammad Basuni bahawa kebiasaan "Ta'liq" iaitu talak yang dikenakan persyaratan dan diucapkan pada saat akad pernikahan. Ia mengatakan bahawa perkara bukanlah merupakan adat dan kebiasaan yang dikenali di kawasan Sambas. Pembatalan pernikahan biasa dilaksanakan melalui jalan fasakh, sudah tentu dengan sebuah alasan yang jelas dan kuat yang dapat di mohonkan kepada Maharaja Imam sebagai mufti yang mengerusi semua perkara yang berhubungkait dengan nikah, talak sehingga fasakh di seluruh kawasan kerajaan Sambas. ${ }^{39}$ Kitab Janaiz (1943), ${ }^{40}$ kitab membahaskan sepuluh masalah yang berhubungkait dengan kematian, bermula pada pembahasan sakit, kematian sehingga mengurus jenazah. Dalam kitab ini juga dikemukakan pelbagai masalah yang menjadi perdebatan di masyarakat Sambas, iaitu masalah talqin, anak orang kafir, bayi yang sudah mati dalam kandungan, ta'riyah dan sebagainya. ${ }^{41}$

Daripada keterangan diatas, tampak begitu nyata bahawa Muhammad Basuni Imran mengambil kira realiti, keperluan 'urf dan maslahah semasa dalam ijtihad hukumnya, sehingga setiap fatwa yang dikeluarkan dapat diterimapakai dan diamalkan dalam kehidupan keagamaan masyarakat Sambas tanpa menimbulkan perselisihan dan percanggahan yang hebat. Semua perkara ini merupakan pengamalan konsep Maqasid al-Shariah dengan sebenar.

${ }^{38}$ Muhammad Basuni Imran, Kitab Nur al-Siraj fi Qissah al-Isra' wa al-Mi'raj (Singapura: Matba'ah al-Ahmadiyah, 1938).

${ }^{39}$ GF. Pijper, Beberapa studi tentang sejarah Islam di Indonesia, 147.

${ }^{40}$ Kitab ini banyak merujuk ke atas kitab al-Umm karya Muhammad bin Idris al-Shafi'i, kitab almuhadhdhab karya Abu Ishak al-Shirazi, kitab al-Mughni karya Ibnu Qudamah. Kitab ini ditulis pada 15 Rabi' al-Awwal $1362 \mathrm{H}$. kitab ini mengandungi 50 halaman muka surat dan diterbitkan oleh Matba'ah al-ahmadiyah Singapura. Muhammad Basuni Imran, Janaiz (Singapura: Mataba'ah al-Ahmadiyah, 1943).

${ }^{41}$ Khairunnisa, "Hukum Islam di Kesultanan Sambas (Studi terbadap peran sultan dan Mabaraja Imam)" (Tesis Sekolah Pasca Sarjana Universitas Islam Negeri syarif Hidayatullah, Jakarta, 2008), 146-149. 


\section{Muhammad Basuni Imran dan Konsep Maslahah Mursalah}

Maslahah mursalah bermaksud kemaslahatan yang keberadaannya tidak disokong syarak dan juga tidak ditolak oleh syarak melalui dalil-dalil yang terperinci, disebut sebagai suatu maslahah, kerana hukum yang ditetapkan berdasarkan maslahah ini dapat mengelakan mukallaf dari suatu bahaya atau kerosakan, dan sebaliknya maslahah tersebut akan mendatangkan kemanfaatan dan kebaikan bagi mukallaf. Demikian halnya, disebut mursalah, kerana Shari' tidak menyetujuinya melalui dalil-dalil khusus, demikian juga tidak menolak secara nyata. ${ }^{42}$

Mustafa Dib al-Bugha mengemukakan bahawa pengamalan maslahah mursalah sebagai dalil dalam menetapkan hukum hanya terhad ke atas permasalahan-permasalahan adat atau mua'malat, kerana secara umumnya hukumnya bersifat ta'aqquli. Selain itu, kerana autoriti dalil maslahah mursalab tidak dapat menetapkan hukum di bidang ibadah yang bersifat ta'abbudi. ${ }^{43}$

Muhammad Basuni Imran memandang bahawa usaha-usaha dalam memajukan perkara-perkara dunia, bukanlah suatu hal yang dilarang dalam syariah Islam, ianya memberikan alasan,

"Adalah suatu kemustahilan bila Rasul dan Khalifahnya menghalangi dan menghambat kemajuan orang-orang dalam kehidupan yang tidak berkaitan dengan akidah dan ibadah, sedangkan mereka memiliki kemampuan, sehingga tidak dapat berbuat apa-apa dengan alasan tidak diizinkan Allah. Bagaimana mungkin akan masuk ke surga Allah kelak di akhirat, kalau memasuki surga kemuliaan di dunia saja tidak dapat". ${ }^{44}$

Terdapat beberapa usaha yang telah dilakukan oleh Muhammad Basuni Imran bagi membina dan mengembangkan sarana keduniawaan yang akan memperkukuh pembinaan keagamaan, antaranya, pertama, bidang pendidikan, beliau mendirikan madrasah al-Sultaniyah yang berada di Kampung Dalam Kaum, berdekatan dengan Sekolab Raja yang telah diasas oleh Belanda pada tahun 1910, kemudian mendirikan al-Kulliyat al-Muballigbin, sebuah pertubuhan bagi pembinaan da $i$ dan mubaligh. Kedua, Menyempurnakan pengelolaan lembaga keimaman dengan komposisi struktur jabatan sebagai berikut,
Maharaja Imam
: H. Muhammad Basuni Imran
Imam Maharaja
: H. 'Abdurrahman Hamid

\footnotetext{
42 Mustafa Dib al-Bugha, Athar al-Adillah al-Mukhtalaf Fiha fi al-Fiqh al-Islami, c. ke-4 (Damskus: Dar al-Qalam, 2007), 35.

${ }^{43}$ Muștafā Dib al-Bughā, Āthār al-Adillah al-Mukhtalaf, 40.

${ }^{44}$ Machrus Effendy, Riwayat Hidup dan Perjuangan Maha Raja Imam Sambas, 48, 72.
} 


$\begin{array}{ll}\text { Imam } & : \text { H. Muhammad Djabir } \\ \text { Khatib } & : \text { H. Muhammad Djubir } \\ & \text { H. Muhammad Mursal } \\ & \text { H. Muhammad Murtada } \\ & \text { H. Muhammad Siddiq } \\ \text { Juru kahwin } & \text { H. Ahmad Sharir (Singkawang) } \\ & \text { H. Muhammad Zahri (Telok Keramat/Paloh) } \\ & \text { H. Muhammad Zainuddin } \\ & \text { H. Miradj Djabir (Bengkayang) } \\ & \text { H. Abdul Azis }\end{array}$

Ketiga, mengirimkan guru-guru agama dan muballigh ke kampungkampung dan kawasan-kawasan pedalaman bagi mengajarkan perkara-perkara agama kepada masyarakat. Dan keempat, Menerbitkan satu media tulisan yang bernama "Risalah Cahaya Sulub" sebagai sarana pembinaan dan peningkatan pendidikan masyarakat.

Kenyataan-kenyataan yang telah diusahakan oleh Muhammad Basuni Imran di atas merupakan pengamalan konsep maslahah al-mursalah dalam pemikiran hukum Islam, meskipun penulis tidak mendapati dalam sebuah karya atau tulisan secara khusus, namun apa yang telah diusahakan Muhammad Basuni Imran bersesuaian dengan konsep maslahah al-mursalah dan juga qawa'id maqasidiyah (kaedah-kaedah dalam konsep maqasid). Sepertimana kaedah yang diungkapkan oleh al-Qarafi: ${ }^{45}$

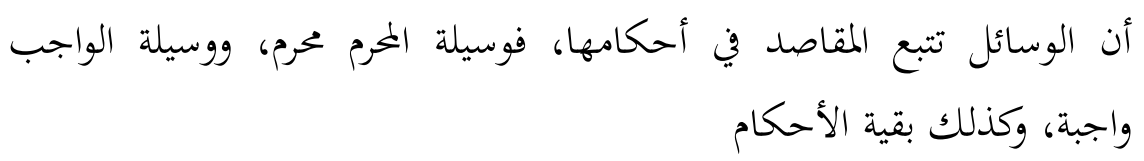

Maksunya: "Bahawa sarana mengikuti bukum maksud dan matlamatnya, sarana yang akan membawa kepada yang haram, maka bukumnya haram, dan sarana yang akan membawa kepada yang wajib, maka bukumnya wajib, dan demikianlah seterusnya".

al-Tufi mengatakan: ${ }^{46}$

$$
\text { أن الوسائل تتبع المقاصد }
$$

Maksunya: "Bahawa sarana mengikuti maksud dan matlamatnya" Manakala Imam al-Shafi'i mengemukakan: ${ }^{47}$

\footnotetext{
45 Al-Qarafi, al-Furuq, 3: 112-113.

46 Al-Tufi, Sharb Mukbtasar al-Raudah (al-Mamlakah al-su'udiyah: Wizarah al-Shu'un alIslamiyyah wa al-awqaf wa al-Da'wah wa al-Irshad, 1419 H/ 1998 M), 3: 89.
} 


$$
\text { الذرائع إلى الحلال والحرام تشبه معاني الحلال والحرام }
$$

Maksunya: "Sarana kepada yang halal dan haram menyerupai makna bukum halal dan haram itu sendirn".

Kenyataan diatas memperlihatkan bahawa Muhammad Basuni Imran mengesan sifat kedinamikan, terbuka dan fleksibiliti ke atas sarana-sarana moden yang boleh digunapakai bagi pembinaan usaha-usaha agama, selama sarana-sarana itu membawa maslahat yang lebih besar.

Muhammad Basuni Imran dan Konsep Politik Ketatanegaraan (Siyāsah Shar'iyyah)

Dalam konsep politik ketatanegaraan Muhammad Basuni Imran memiliki pandangan yang sangat jelas, politik menurut Muhammad Basuni Imran merupakan bahagian daripada prinsip-prinsip iman dan tauhid seorang muslim. Dalam karya bidang tauhid iaitu Kitab Bidayah al-Taubid fi 'ilm al-Taubid, Muhammad Basuni Imran mengatakan:

"Mengangkat Imam, raja atau pemimpin Negara wajib bagi orang-orang Islam. Syarat seorang pemimpin adalah keturunan Quraysh, muslim, merdeka, laki-laki, berakal, dewasa, pandai siasat dan mampu membangun". ${ }^{48}$

Tidak hanya setakad teori, secara praktikal Muhammad Basuni Imran hampir di sebahagian besar masa hidupnya berhubungan dengan jawatanjawatan penting dalam pemerintahan kesultanan Sambas, antaranya pertama, Maharaja Imam di kesultanan Sambas (1913-1946), adalah Jawatan yang paling masyhur, Kedua, Kepala Madrasah al-Sultaniyah (1919-1935), pada masa Sultan Muhammad Safiyuddin II, yang lembaga pendidikan di persekitaran istana yang memberikan pendidikan dasar agama dan ilmu-ilmu umum bagi kerabat sultan, kanak-kanak pejabat kesultanan dan masyarakat di kawasan istana, ketiga, Adviseur Cammissie voor ZelfBestuur (1946-1950) iaitu jawatan rasmi Penasehat Pemerintahan Otonomi di Sambas daripada pemerintahan Belanda, keempat, Penata hukum tingkat I atau ketua pengadilan agama Mahkamah syariah Kalimantan Barat (1966-1975) dan kelima, ahli Konstituante Republik Indonesia wakil daripada parti Masyumi (Majlis Syuro Muslimin Indonesia) Kalimantan Barat hasil daripada pemilu raya I, tahun 1955.

\footnotetext{
${ }^{47}$ Al-Shafi'i, al-Umm, 4:57.

48 Muhammad Basuni Imran, Bidayah al-Taubid fi ilm al-Taubid (Singapura: Matba'ah alAhmadiyah, $1336 \mathrm{H} / 1918 \mathrm{M}), 42-43$.
} 
Muhammad Basuni Imran juga mereformasi dan menyempurnakan pengelolaan lembaga keimaman dengan komposisi struktur jawatan yang lebih efektif, seperti yang tampak dalam jadual 5.1 berikut: $^{49}$

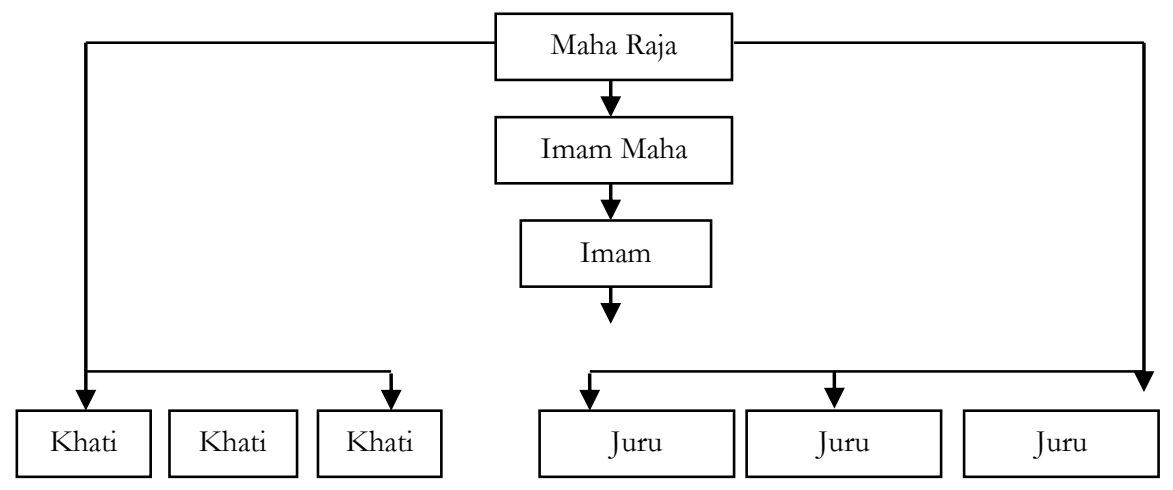

Daripada jadual di atas, tampak jelas bahawa mulai dari Maharaja Imam, Imam Maharaja dan Imam merupakan jawatan tertinggi yang berkedudukan di pusat kerajaan. Sedang khatib dan Juru Kahwin berkedudukan di Bandar atau kampong dan bertanggung jawab langsung kepada Maharaja Imam. Imam Maharaja merupakan wakil dari Maharaja Imam, sedangkan Imam dan Khatib adalah petugas dalam pelaksanaan shalat jumat di masjid-masjid, adapun juru kahwin bertugas dalam hal pencatatan perkahwinan.

Konsep dan amalan tentang politik ketatanegaraan yang telah diusahakan oleh Muhammad Basuni Imran tidak terlepas daripada kesan persekitaran tempatan mahupun keilmuan dimana beliau hidup. Muhammad Basuni Imran hidup dalam keluarga yang berperanan dalam jawatan-jawatan keagamaan di kesultanan Islam Sambas. Kakek Muhammad Basuni Imran iaitu H. Muhammad Arif merupakan Maha raja Imam pertama di kesultanan Islam Sambas, manakala H. Muhammad Imran ayahanda Muhammad Basuni Imran merupakan Maha raja Imam kedua di kesultanan Islam Sambas, persekitaran ini sudah tentu akan memberikan kesan yang mendalam dalam pembinaan pemikiran dan keperibadian Muhammad Basuni Imran.

Perjalanan keilmuan Muhammad Basuni Imran juga mempertemukannya dengan tokoh-tokoh yang memiliki perhatian yang sangat

49 Machrus Effendy, Riwayat Hidup dan Perjuangan Maha Raja Imam Sambas, 29-30. Pabali, Mubammad Basuni Imran (1883-1976), 46. 
besar terhadap keadaan dan situasi politik umat Islam seperti Sayid Muhammad Rasyid Rida, pemilik majalah "al-Manar", guru Muhammad Basuni Imran semasa di Mesir merupakan tokoh reformis yang terkesan dengan pemikiranpemikiran Muhammad Abduh dan Jamaludin al-Afgani. Kesan ini masih tampak sebegitu mendalam selepas kepulangannya ke Nusanntara, dengan adanya kominikasi yang berterusan dalam mengkongsikan pelbagai masalahmasalah keummatan, seperti yang tampak dalam pertanyaan Muhammad Basuni Imran ke atas majalah al-Manar tentang "Limadha taakhar al-Muslimuna wa limadha taqaddama ghairubum?" (Mengapa Ummat Islam mundur dan orang lain maju?)" menjadi tajuk buku dengan judul yang sama yang ditulis oleh Amir Shakib Arselan (1869-1945). Terjemahannya ke bahasa Inggeris berjudul "Our Decline and its Causes" terbit di Lahore Pakistan tahun 1944, ${ }^{50}$ dan terjemahan ke dalam bahasa Indonesia diterbitkan pada tahun 1970-an.

Oleh itu, tidak menghairankan jika gagasan dan pemikiran politik Muhammad Basuni Imran kemudian diwujudkan dalam sebuah usaha reformasi ketatanegaraan yang dijangka akan lebih efektif untuk membawa kepada kejayaan Islam dan ummatnya.

\section{Muhammad Basuni Imran dan Konsep al-Tahaluf al-siyasi}

Fenomena yang cukup menarik dari sumbangan pemikiran hukum Islam ulama Kalimantan Barat abad ke-19 dan 20 adalah konsep al-Tahaluf alSiyasi.

Secara sederhana al-Tabaluf al-Siyasi bermaksud ikrar persefahaman untuk bekerjasama dan saling membantu bagi mencapai objektif tertentu. ${ }^{51}$ Persefahaman sepertimana ini dilakukan bagi mengelakan bahaya yang sama atau yang lebih besar dengan tujuan untuk menegakan yang makruf dan mewujudkan keadilan, sama ada sesama muslim mahupun non muslim untuk menghadapi musuh bersama. ${ }^{52}$

Munir Muhammad Ghadban metakrifkan al-Tahaluf al-Siyasi sebagai kaedah rundingan kerjasama dua hala dalam menghadapi masalah atau konflik

\footnotetext{
${ }^{50}$ G. F. Pijper, Beberapa Studi tentang Sejarah Islam di Indonesia 1900-1950, terj. Tudjimah \& Yessy Augusdin (Jakarta: UI Press, 1984), 148-149.

${ }^{51}$ Mohd Syakir Mohd Rosdi, "Tabaluf Siyasi Zaman Nabi SAW: Kajian Awal Persejarahan", in Warjio, ed., Politik Pembangunan Islam - Pemikiran dan Implementasi (Medan: Perdana Publishing, pp. 2013a), 187. Muhammad Syukri Salleh et.al," Islamic Political Economy: A Special Reference to the Use of Tabaluf Siyasi in the State of Kelantan, Malaysia," (American International Journal of Contemporary Research. May 2014, Vol. 4, No. 5), 124.

52 Ibid.
} 
supaya objektif mereka terlibat boleh dicapai selagi ia tidak melanggar prinsipprinsip Islam. ${ }^{53}$

Manakala Muhammad 'Izzat Saleh 'Unayni mendifanasikan al-Tahaluf al-Siyasi sebagai kesepakatan dan perjanjian serta usaha untuk saling membantu ke atas perkara yang mubah secara shar'i, diantara dua kelompok politik atau lebih dengan tujuan merealisasikan tujuan politik yang disepakati, sama ada bersifat sementara mahupun berkekalan. ${ }^{54}$

Para pakar politik Islam mensyaratkan dalam konsep Tabaluf Siyasi mesti memenuhi beberapa syarat utama, pertama, perjanjian itu dilakukan oleh sekumpulan orang yang memiliki keupayaan dalam ilmu mahupun pertimbangan, dan ianya bukanlah seorang hamba sahaya, kedua, kontrak perjanjian (akad) perlu bebas daripada apa-apa kuasa dan pengaruh ketiga, perlu ada perjanjian tertentu dan jelas; dan keempatnya, perjanjian dan kandungannya tidak bercanggah dengan undang-undang Islam. ${ }^{55}$

Muhammad Basuni Imran misalnya menjawat Maharaja Imam Mufti kerajaan Sambas (1913-1946), semasa kekuasaan kolonial Inggeris di kesultanan Sambas semenjak tahun $1813,{ }^{56}$ seterusnya kolonial Belanda semenjak tahun 1818, dengan didirikannya kantor perwakilan Belanda di Sambas. ${ }^{57}$ Pemerintahan kerajaan Islam Sambas yang tidak lagi secara penuh diatur dengan syariah Islam, namun telah masuk campur tangan daripada kolonial barat, malahan beliau menerima jawatan sebagai Adviseur Cammissie voor ZelfBestuur (1946-1950) iaitu jawatan rasmi Penasehat Pemerintahan Otonomi di Sambas daripada pemerintahan Belanda.

Apa yang diusahakan oleh Muhammad Basuni Imran ini sesungguhnya merupakan pengamalan ke atas konsep al-Tahaluf al-Siyasi dalam sistem politik moden, yakni mengambil langkah kompromi, persefahaman untuk bekerjasama dan saling membantu bagi mencapai objektif yang di jangka akan merealisasikan maslahah yang lebih besar dan mengelakan daripada bahaya

\footnotetext{
${ }^{53}$ Munir Muhammad Ghadban, al-Tahaluf al-Siyasi Fi al-Islam, c. 1 (al-Urdun- Zarqa': Maktabah al-Manar, 1982), 6-7.

${ }^{54}$ Muhammad 'Izzat Saleh "Unayni, "Ahkam al-Tahaluf al-Siyasi fi al-Figh al-Islamy” (Disertasi, Jami’ah al-Najah al-Wataniyyah Palestina, 2008), 37.

${ }^{5}$ MasturaTani , "Perjanjian 'Aqabab: peranannya dalam pembentukan negara Islam Madinab," (Academic Exercise (B.A), Department of Siasah Shar'iah, Akademi Pengajian Islam, Universiti Malaya, unpublished, 1999. Muhammad Syukri Salleh et al., Muhammad Syukri Salleh et al., Islamic Political Economy: A Special Reference, 124.

${ }^{56}$ Irwin, Borneo Abad Kesembilan belas, 33.

${ }^{57}$ Ibid., 63.
} 
yang sama atau yang lebih besar, sebab perkara inilah yang menjadi matlamat sebenar dalam sistem siyasah shar'iyah iaitu untuk melaksanakan maqasid alShariah yang terkandung di dalam perkara yang berkaitan dengan "jalb alMasalib" (mendapatkan kemaslahatan kepada manusia) dan "dar' al-Mafasid" (menghilangkan kemudaratan daripada mereka), sepertimana pernyataan Ibn 'Āqil tentang Siyasah Shar'iyyah ialah : "Suatu tindakan oleh pemimpin yang boleh menyelamatkan orang ramai dan menghindarkan mereka dari kehancuran, walaupun tindakan tersebut tidak dilakukan oleh Rasulullah s.a.w. atau pun tidak ada wabyu berkenaan perkara tersebut" ${ }^{58}$

Menerimapakai jawatan dalam persekitaran kerajaan yang telah jatuh dalam kuasa dan pengaruh kolonial adalah lebih membawa maslahat dan mengelakan mudarat (bahaya) yang lebih besar berbanding mengabaikannya. Sudah tentu, keputusan ini tidak terkeluar daripada pelbagai pertimbangan, beberapa pertimbangan yang boleh di jangka antaranya, pertama, membuka peluang untuk lebih merealisasikan lima dasar-dasar objektif syariah (Maqasid al-shari'ab) iaitu: Hifzu al-Din (Kewajiban menjaga agama), Hifæu al-'Aqli (kewajiabn menjaga akal), Hif₹u al-Nafs (Kewajiban menjaga jiwa), Hif₹u al-Irdi (Kewajiban menjaga kehormatan) dan Hifæu al-Mal (Menjaga Harta kekayaan).kedua, merealisasikan Islam yang bersifat universal, ketiga, mengenalpasti program dan strategi kolonial dalam usaha memperlemah kekuatan umat Islam, keempat, menghentikan program-program kolonial yang akan membawa bahaya ke atas umat Islam, kelima, membuka peluang untuk membuat enakmen yang akan membawa maslahat umat, keenam, penyebaran dakwah dalam semua sisi kehidupan terutama dalam politik ketatanegaraan.

Usaha-usaha yang dilakukan oleh para ulama dan tokoh Kalimantan Barat abad ke-20 ini selari dengan kaedah-kaedah usul maqasidiyah sepertimana yang banyak dikenalkan oleh para ulama usul, antaranya :

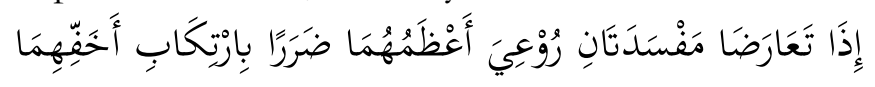

Maksunya: "Apabila berlaku percanggahan diantara dua kerosakan, maka dipelibara kerosakan yang terbesar dengan melakukan kerosakan yang lebih kecil”. ${ }^{59}$

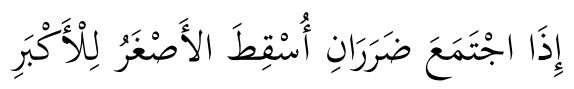

\footnotetext{
${ }^{58}$ Ibn Qayyim al-Jawziyyah, al-Turuq al-Hukmiyyah Fì al-Siyāsah al-Sharíyyah, 11.

${ }^{59} \mathrm{Jalal}$ al-Din Abd al-Rahman bin Abu Bakr al-Suyuti, al-Ashbah wa al-Naqa'ir (Beirut: Dar alKutub al-'Ilmiyah, 1399 H), 87.
} 
Maksunya: "Apabila berbimpun dua babaya maka bahaya yang lebib kecil digugurkan bagi mengelakekan bahaya yang lebih besar".

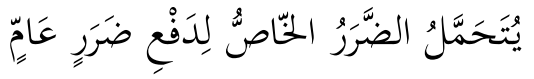

Maksunya: "Bahaya yang bersifat khusus dipelihara bagi mengelakekan bahaya yang bersifat umum". ${ }^{61}$

\section{Muhammad Basuni dan Fiqh Tempatan}

Pembinaan Figh tempatan juga tampak dalam fatwa Muhammad Basuni Imran tentang jumlah jamaah salat Jumaat, beliau lebih berpegang ke atas qaul qadim Imam al-Shafi'i berbanding qaul jadidnya yang menyatakan sahnya salat jumaat oleh jamaah yang kurang daripada empat puluh orang. Ijtihad ini dipilih oleh Muhammad Basuni Imran dengan mempertimbangkan keadaan tempatan dimana masyarakat sambas yang bercerai-cerai dalam ramai kawasan dan tidak berkumpul dalam satu kawasan. ${ }^{62}$ Muhammad Basuni Imran menyatakan,

"Jumaat itu sah dikerjakan dengan orang yang kurang daripada empat puluh, maka atas qaul Imam Shafi'i yang qadim sah jumaat dengan empat orang dan Hadith Muslim yang tersebut menunjukkan bahawa Nabi S.A.W. telah sembahyang jumaat dengan dua belas tetapi ini hadits tiada jua menunjukkan bahawa shalat jum'at tiada sah dengan orang yang kurang dari pada dua belas apalah lagi dari pada empat puluh. Jadinya kalau didapati pada satu desa orangnya tiada sampai empat puluh dan mereka itu tiada dapat sama sekali hendak pergi ke jumaat yang sempurna empat puluh kerana terlalu jauh umpamanya, maka wajiblah atas mereka itu mendirikan jumaat pada tempat (desa) mereka itu. Ataupun mereka itu boleh pergi kepada jumaat yang sempurna itu dengan mashaqqah dan susah payah oleh kerana sangat jauh niscaya harus mereka itu mendirikan jumaat di tempat mereka itu dan harus mereka itu pergi kepada jumaat yang sempurna itu, mengertinya boleh memilih antara dua hal itu". ${ }^{63}$

Syeikh Muhammad Basuni telah mengemukaka pendapatnya dengan dua pendekatan, pertama, pendekatan naqli dengan berdasarkan pada hadith

\footnotetext{
${ }^{60}$ Abu al-'Abbas Ahmad bin Yahya al-Wansharisi, Idah al-Masalik ila qawa'id al-Imam Malik (Maghrib: Matba'ah Fadalah al-Muhammadiyah, 1400 H), 370.

${ }^{61}$ Ibnu Najim Zain al-Din bin Ibrahim, al-Ashbah wa al-Nazair (Beirut: Dar al-Kutub al'Ilmiyyah, $1400 \mathrm{H}), 87$.

${ }^{62}$ Basuni Imran, Risaalah Cahaya Suluh. Pada Mendirikan Jum at Kurang daripada Empat Pulub, (Singapura: penerbit al-Ikhwan, 1339 H/ 1920M).

${ }^{63}$ Basuni Imran, Risalah Cabaya Sulub, 9-10.
} 
yang dikeluarkan oleh Imam Muslim daripada Sahabat Jabir bin Abdullah, bahwasanya Nabi S.A.W. saat itu sedang membaca khutbah pada hari jum'at, maka datanglah kafilah dagang daripada negeri Sham, maka berpalingah jamaah jumat ketika itu, sehingga tidak tinggal kecuali dua belas orang laki-laki, maka turunlah ayat:

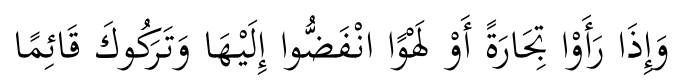

Terjemahan: Dan apabila telah melihat mereka itu akan perniagaan atau permainan, nescaya pergilab mereka itu kepadanya dan mereka meninggalkanmu dalam keadaan berdiri. (Al- Jumu'ah: 60: 11)

Berkatalah Imam Nawawi dalam sharah itu bahawa itu adalah dalil bagi Imam Malik dan yang lainnya ke atas sahnya jum'at dengan dua belas orang laki-laki". ${ }^{64}$ Kedua, Muhammad Basuni Imran menggunapakai pendekatan Aqli, iaitu pertimbangan sosial dan persekitaran masyarakat Sambas, dimana jumlah penduduknya bercerai-cerai dalam ramai kawasan dan tiada berkumpul dalam satu kawasan. Jika mereka mengikut mazhab Shafi'i (qaul al-Jadid), maka salat jumaat tidak dapat di laksanakan. Oleh itu Syeikh Muhammad Basuni seterusnya menyatakan,

"Wajib atas tiap-tiap ahli desa itu mendirikan sembahyang jumaat di tempat mereka itu atas qaul jadid, apalah lagi qaul qadim. Tentang tiada cukup empat puluh yang dating sembahyang itu, maka ini tiada menghilangkan wajib mendirikan jumaat di tempat mereka itu. Maka siapa-siapa yang tiada dating, hadir sembahyang itu, maka ia berdosa dan merasa siksa Allah ta'ala. Dan janganlah ia sangka bahawa orang yang sembahyang itu telah melepaskan tanggungannya, kerana jum'at ini fardu 'ain bukan fardu kifayah". ${ }^{5}$

Namun demikian, Syeikh Muhammad Basuni tetap bersikap fleksibel dan moderat dengan memberikan dua pilihan, pertama, jika tidak memungkinkan untuk pergi ke tempat lain yang ramai jamaahnya kerana jarak yang jauh, maka mereka wajib melaksanakan jumaat di desanya sahaja. Kedua, jika memungkinkan untuk pergi ke tempat jamaahnya lebih empat puluh, maka mereka harus pergi ke tempat jumaat yang sempurna. Apa yang diusahakan oleh Syeikh Muhammad Basuni bersesuaian dengan kaedah yang dikenalkan oleh Imam Ibn al-Qayyim :

\footnotetext{
${ }^{64} \mathrm{Al}$ - Nawawi, Sabih Muslim bi Sharb al-Nawawi, c.1 (Dar Abi Hayyan, 1415 H/1995 M), 3:416.

${ }^{65}$ Basuni Imran, Risalab Cahaya Sulub, 10.
} 


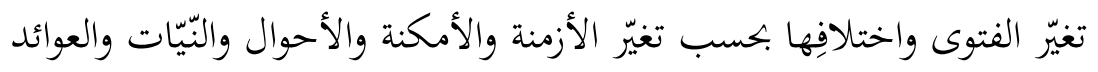

Maksudnya: "Perubahan dan perbezaan fatwa mengikut perubahan masa, tempat, keadaan, niat dan kebiasaan".

\section{Simpulan}

Daripada huraian diatas, bolehlah disimpulkan bahawa Muhammad Basuni Imran merupakan tokoh dan ulama Kalimantan Barat yang popular pada abad ke-20, Maharaja Imam kesultanan Sambas, pandangannya menurut G.F. Pijper telah mewakili reformasi Mesir yang sebenar di Indonesia dengan corak utama tradisionalism, inklusifism, menghargai Turath (warisan ilmu para ulama), mesra dalam wasilah, kukuh dalam thawabit (perkara-perkara yang tetap) namun lentur dalam mutaghayyirat (perkara yang berubah).

Pemikiran pembaharuannya meliputi beberapa aspek utama, antaranya aspek maqasid shariah melalui penggunaan konsep tadarruj (bertahap) dalam mengemukakan idea pembaharuan serta penggunaan konsep Maslahah Mursalah dalam melakukan pembaharuan bidang pembinaan pemerintahan dan konsep al-Tahaluf al-Siyasi juga tampak melalui kedua tokoh ini dalam menerimapakai jawatan di persekitaran kerajaan yang telah jatuh dalam kuasa dan pengaruh kolonial. Aspek siyasah shar'iyyah melalui pembaharuan ke atas pengelolaan lembaga keimaman yang lebih efektif, neo-sufism melalui melalui usaha reapproachement (pendekatan) ajaran tasawuf dan syari'ah serta usaha pemurnian (purivication) ajaran tasawuf daripada bid'ah, tahyul dan khurafat. Dan konsep aspek fiqh tempatan tampak melalui usaha pembinaan idea pembaharuan melalui dua farsa bagi meraikan keadaan dan mentaliti masyarakat dan ijtihad sahnya salat jum'at kurang daripada empat puluh orang.

\section{Daftar Pustaka}

Abu al-'Abbas Ahmad bin Yahya al-Wansharisi, Idah al-Masalike ila qawa'd alImam Malik (Maghrib: Matba'ah Fadalah al-Muhammadiyah, $1400 \mathrm{H}$ ), A Muis Isma'il, Mengenal Mubammad Basuni(Maharaja Raja Sambas) (Pontianak: FISIP Universitas Tanjungpura, 1993). Asal Raja-Raja Sambas, (Manuscrip, Perpustakaan Nasional No. ML.696). Aqib Suminto (1996), Politik Islam Hindia Belanda. Jakarta: LP3ES

${ }^{66}$ Ibn al-Qayyim al-Jauziyyah, I'lam al-Munaqqi'in 'an Rabb al-'Alamin, c. 1 ( Riyad: Dar Ibn alJauzi, 1423 H), 4:337. 
Al-Tufi, Sharb Mukbtasar al-Raudah (al-Mamlakah al-su'udiyah: Wizarah alShu'un al-Islamiyyah wa al-awqaf wa al-Da'wah, wa al-Irshad, 1419 H/ 1998 M).

Al - Nawawi, Sabih Muslim bi Sharh al-Nawawi, c.1 (Dar Abi Hayyan, 1415 $\mathrm{H} / 1995 \mathrm{M})$,

Christiaan Snouck Hurgronje. Safahat min Tarikhi Makkah dirasah li al-auda' alsiyasiyah wa al-Ijtima'iyyah wa al-Iqtisaddiyah min al-Bithah al-Nabawiyah alSharifah wa hatta nihayat al- Qarn al- Thalits 'Ashar al- Hijri, ed. 'Ali 'Audah al-Shuyukh (Dar al-Malik 'Abd 'Aziz, 1419 H).

G. F. Pijper, Beberapa Studi tentang Sejarah Islam di Indonesia 1900-1950, terj. Tudjimah \& Yessy Augusdin (Jakarta: UI Press, 1984) , Studien Over de Geschiedenis Van De Islam In Indonesia 1900-1950 (Netherlands: E.J. Brill Leiden, 1977).

Graham Irwin. Borneo Abad Kesembilan Belas. Terj. Mohd. Nor Ghani dan Noraini Ismail, c. 2. Kuala Lumpur: Dewan Bahasa dan Pustaka, 2006.

Ibn Qayyim al-Jawziyyah, al-Turuq al-Hukmiyyah Fì al-Siyäsah al-Shariyyah, Beirut: Dār al-Kutub al-'Tlmiyyah, t.t.

, I'lam al-Munaqqi'in 'an Rabb al-'Alamin, c. 1 ( Riyad: Dar Ibn al-Jauzi, $1423 \mathrm{H}$ ),

Ibnu Najim Zain al-Din bin Ibrahim, al-Ashbah wa al-Nazair (Beirut: Dar alKutub al-'Ilmiyyah, $1400 \mathrm{H}$ )

Jalal al-Din Abd al-Rahman bin Abu Bakr al-Suyuti, al-Ashbah wa al-Naza'ir (Beirut: Dar al-Kutub al-'Ilmiyah, 1399 H)

Khairunnisa, "Hukum Islam di Kesultanan Sambas (Studi terhadap peran sultan dan Maharaja Imam)" (Tesis Sekolah Pasca Sarjana Universitas Islam Negeri syarif Hidayatullah, Jakarta, 2008),

Machrus Effendy (1995), Riwayat Hidup dan Perjuangan Maba Raja Imam Sambas, Jakarta: P.T. Dian Kemilau.

Mahmud Yunus (1996), Sejarah Pendidikan Islam di Indonesia. Jakarta: Hidakarya Agung.

MasturaTani , "Perjanjian 'Aqabah: peranannya dalam pembentukan negara Islam Madinah," (Academic Exercise (B.A), (Department of Siasah Shar'iah, Akademi Pengajian Islam, Universiti Malaya, unpublished, 1999)

Muis Isma'il (1993), Mengenal Mubammad Basuni(Maharaja Raja Sambas). Pontianak: FISIP Universitas Tanjungpura.

Muhammad Basuni 'Imran, Risalah Cahaya Sulub (Singapura: Al-Ikhwan, $1339 \mathrm{H})$. 
, Khulasah Sirah al-Muhammadiyah (Singapura: Matba'ah al-ahmadiyah, 1932).

, Kitab Nur al-Siraj fi Qissah al-Isra' wa al-Mi'raj (Singapura: Matba'ah alAhmadiyah, 1938).

, Janaiz (Singapura: Mataba'ah al-Ahmadiyah, 1943).

, Bidayah al-Taubid fi 'ilm al-Taubid (Singapura: Matba'ah al-Ahmadiyah, 1336 H/ 1918 M), ah wa al-Irshad, 1419 H/ 1998 M).

Mustafa Dib al-Bugha, Athar al-Adillah al-Mukbtalaf Fiha fi al-Fiqh al-Islami, c. ke-4 (Damskus: Dar al-Qalam, 2007),

Muhammad 'Izzat Saleh 'Unayni, "Ahkam al-Tahaluf al-Siyasi fi al-Fiqh al-Islamy" (Disertasi, Jami’ah al-Najah al-Wataniyyah Palestina, 2008)

Mohd Syakir Mohd Rosdi, "Tahaluf Siyasi Zaman Nabi SAW: Kajian Awal Persejaraban", in Warjio, ed., Politik Pembangunan Islam - Pemikiran dan Implementasi (Medan: Perdana Publishing, pp. 2013a)

Muhammad Syukri Salleh et.al," Islamic Political Economy: A Special Reference to the Use of Tahaluf Siyasi in the State of Kelantan, Malaysia," (American International Journal of Contemporary Research. May 2014, Vol. 4, No. 5)

Munir Muhammad Ghadban, al-Tahaluf al-Siyasi Fi al-Islam, c. 1 (al-UrdunZarqa': Maktabah al-Manar, 1982)

"Pahlawan Nasional : K. H. Agus Salim," dicapai 26 Mei 2016, http://indonesiaindonesia.com/f/4328-pahlawan-nasional-k-h-agussalim/.

Pabali H.Musa (2003), Sejarah Kesultanan Sambas Kalimantan Barat, c. 1. Pontianak: Percetakan Romeo Grafika. ,(1999), "Mubammad Basuni Imran (1883-1976), Rekonstruksi Pemikiran ,Maharaj Imam Sambas-Kesultanan Sambas Kalimantan Barat." Tesis Program Magsiter Pemikiran Islam, IAIN Syarif Hidayatullah. ,(2002), Kiprah anak zaman, gagasan, pemikiran dan buah karya Maharaja Imam Sambas H. Basyuni Imran. Pontianak: Pusat Penelitian Budaya Melayu Universitas Tanjung Pura 